\title{
DOMINIKA ŁUKOSZEK
}

InSTYTUT FILOZOFII

Uniwersytet im. Adama Mickiewicza w Poznaniu

\section{FILOZOFIA MIĘDZYKULTUROWA - NOWE SPOJRZENIE NA FILOZOFIE}

\author{
"Philosophy is the reaction of the whole of man to the \\ whole of reality".
}

Krishna Roy [za: Škof, 2010: 51]

W 1995 roku odbył się w Meksyku pierwszy międzynarodowy kongres filozofii międzykulturowej. Jego inicjatorami byli filozofowie latynoamerykańscy na czele z Raulem Fornet-Betancourtem. Punktem wyjścia dla tego międzykulturowego spojrzenia na filozofię było przekonanie o konieczności odnowy i przekształcenia filozofii - w odniesieniu zarówno do metody uprawiania filozofii, jak i do edukacji z zakresu przedmiotu „filozofia”. W swoim artykule chciałabym przybliżyć polskiemu czytelnikowi to podejście w związku ze znikomą ilością publikacji w języku polskim dotyczących tego tematu oraz - mam nadzieję - skłonić do dalszych poszukiwań i odkryć już we własnym zakresie. W artykule odniosę się do spostrzeżeń wspomnianego powyżej Raula Fornet-Betancourta oraz do poglądów Franza Wimmera, a w końcowej części nawiążę również do debaty nad przyszłością nauk społecznych w zglobalizowanym świecie i konieczności ich uprawiania właśnie w ujęciu międzykulturowym.

Podążając za myślą Fornet-Betancourta zacznijmy najpierw od przewrotnego wyjaśnienia czym filozofia międzykulturowa nie jest: nie jest to bowiem żadna nowa dyscyplina filozoficzna, ani też nowe sformułowanie tej części filozofii, którą określamy mianem filozofii kultury. Nie jest to również nowa postać filozofii porównawczej. A czym międzykulturowa filozofia w takim razie jest? Jest ona nowym podejściem do filozofii, które podejmuje próbę sprowokowania dyskusji nad zmianą paradygmatu w odniesieniu do metody uprawiania filozofii. Podejmowane działania polegają na przełamywaniu barier utworzonych przez monokulturowe struktury tradycyjnej filozofii, lub - używając bardziej pozytywnych sformułowań - na kultywowaniu takiego 
podejścia w filozofii, którego punktem wyjścia jest uznanie wielości filozofii wraz z ich kulturowymi kontekstami i sposobami argumentowania oraz uzasadniania. Myślenie owo charakteryzuje nie tylko tolerancja wobec odmiennych sposobów postrzegania świata, ale pewna solidarność wobec innych sposobów myślenia. Filozofia międzykulturowa uznaje różnorodność kulturową za bogactwo wszystkich ludzi i broni ich praw do posiadania i kultywowania ich własnej kultury [Fornet-Betancourt, 2002: 230].

Filozofia międzykulturowa wychodzi od stwierdzenia, że tradycyjny paradygmat filozofii, mający swe źródło w starożytnej Grecji i gloryfikujący racjonalność, wyczerpał już swoje możliwości rozwoju, a ponadto paradygmat ten wykazywał roszczenie do uniwersalności. W związku z tym należy „odfilozofować” filozofię i zdecydowanie zrewidować dotychczasowe metody jej uprawiania. W praktyce oznacza to, że filozofia mająca zakusy uniwersalne powinna uznać dialog za swoją podstawę. Jednak aby postulowany dialog miał szansę zaistnieć, należy przekształcić samo pojęcie filozofii. Filozofia w tym nowym ujęciu powinna uznać, że istnieją różne sposoby myślenia, nie zawsze respektujące wymóg autonomii rozumu, który przez wieki na dobre zakorzenił się w myśli Zachodu. Narzędziami w tym dialogu miałyby być zaproponowane przez Raimundo Panikkara tzw. odpowiedniki homeomorficzne. Są to pewne odpowiedniki funkcjonalne, zadaniem których byłoby przedstawienie i zrozumienie kategorii, wydawałoby się zupełnie ze sobą niekorespondujących, ale spełniających podobne funkcje w danych światopoglądach. Panikkar jako przykład takich odpowiedników podaje Boga i Brahmana [Wojcieszak, 2006: 207].

Radykalną propozycję filozofii międzykulturowej znajdujemy w pracy Josefa Estermana poświęconej „filozofii andyjskiej” [Esterman, 1978]. W podtytule swej pracy Esterman dopowiada, że jest ona poświęcona „autochtonicznej mądrości andyjskiej”. Tym samym rzuca wyzwanie tradycyjnie rozumianej filozofii, bowiem filozofia andyjska wielokrotnie zaprzecza wymogom ustanowionym dla filozofii w toku wielowiekowej tradycji. Jak podaje Janusz Wojcieszak filozofia andyjska to „(..) filozofia zazwyczaj anonimowa, nie zobiektywizowana w pisanych tekstach filozoficznych, lecz oparta o tradycję ustną. Podmiot tej filozofii jest podmiotem zbiorowym w tym sensie, że każdy Indianin andyjski (runa) może być jej wyrazicielem w swoich często nieuświadamianych i podzielanych ze wspólnotą doświadczeniach życiowych. Filozofia andyjska uznaje za fundament rzeczywistości - swoistą jej substancję - zasadę wzajemnego związku i współzależności (...). Powszechność zasady relacyjności sprawia, że w filozofii andyjskiej jednostka istnieje o tyle, o ile znajduje się w sieci powiązań $\mathrm{z}$ innymi (...), o ile funkcjonuje we wspólnocie. $\mathrm{Z}$ tego też 
powodu wykluczenie jednostki ze wspólnoty równoznaczne jest z jej unicestwieniem. Logika andyjska rządzi się także prawami relacyjności, odpowiedniości i wzajemności. Wartości etyczne, odwołujące się do tych praw, znajdują swoje ostateczne umocowanie $\mathrm{w}$ idei porządku kosmicznego. (...) to nie rozum w filozofii andyjskiej jest narzędziem poznania, ale instrumenty nieracjonalne, takie jak zmysły, uczucia, emocje, przeczucia, wyobrażenia" [ibidem: 208].

W ujęciu latynoamerykańskim zadanie, jakie staje przed filozofią, to nie tylko przeformułowanie pojęcia filozofii jako dyscypliny naukowej, ale również (a może przede wszystkim) stymulowanie zmian w sferze działań społeczno-ekonomicznych i to w skali całego globu. Widać tu dążenie do przezwyciężenia postrzegania tego, co dzieje się w tej części świata, jako wydarzeń peryferyjnych, a także dążenie do równouprawnienia różnych tradycji filozoficznych w dyskursach filozoficznych [ibidem: 209]. Podsumowując słowami Fornet-Betancourta, filozofia międzykulturowa „(...) nie tylko jest antyeurocentryczna, nie tylko uwalnia filozoficzność od ograniczania do tradycji europejskiej, lecz krytykuje również jej wiązanie z jakimś centrum kulturowym" [Szulakiewicz, 2006: 140].

Również w podejściu Franza Wimmera [Wimmer, 1996] przebrzmiewają wymienione wyżej postulaty. Stawia on pytanie o to, jaką metodę uprawiania filozofii należałoby przyjąć, aby móc mówić o filozofii o zakusach uniwersalnych. Pyta również, jaka będzie rola poszczególnych tradycji w kształtowaniu tego nowego sposobu myślenia, a także rewiduje dotychczasowy sposób patrzenia na historię filozofii.

Wimmer przypomina, że współczesne filozofowanie jest zależne od uwarunkowań kulturowych oraz że filozofia powstała nie tylko w Europie, ale również $\mathrm{w}$ wielu innych miejscach - jeśli przyjmiemy, że podstawowe pytania filozoficzne dotyczą głównie trzech obszarów: co istnieje, jak to poznajemy, co jest słuszne, czyli innymi słowy - uznamy ontologię, epistemologię oraz etykę za centralne obszary dociekań filozoficznych. Zwraca też na to uwagę Marek Szulakiewicz pisząc: „Pojęcie «filozofia» pochodzi od Greków, lecz «sprawy» jakimi zajmuje się ona wcale nie są ograniczone do języka i kultury greckiej. Filozofia i filozofowanie rodzi się, powstaje i rozwija w pewnej sytuacji. Stąd też mamy zawsze do czynienia z kulturowym kontekstem odpowiedzi. (...) pytania są uniwersalne, a odpowiedzi są wyrazem kultur i historii” [Szulakiewicz, 2006: 143].

Mówiąc o międzykulturowym podejściu do filozofii, Wimmer poddaje refleksji cztery zagadnienia: zaczyna od omówienia ogólnego spojrzenia na historię filozofii, zwraca uwagę na związek filozofii z językiem, w jakim jest ona wyrażona, podnosi kwestię tzw. etnofilozofii oraz mówi o konsekwen- 
cjach dla historiografii filozofii, jeśli zdecydujemy się na międzykulturowe podejście do tej dyscypliny.

Historia filozofii to - twierdzi Wimmer - historia opowiadana przede wszystkim przez filozofów i historyków filozofii w Europie. To przede wszystkim historia niepowtarzalnego i rozwijającego się rozumu ludzkiego, którego głównymi przedstawicielami byli - tak się akurat złożyło - biali mężczyźni ze świata zachodniego. W publikowanych dziejach historii filozofii, jeśli już pojawia się opis historii myśli chińskiej lub hinduskiej, to zwykle ogranicza się on do starożytności. Z drugiej strony, jeśli już pojawi się informacja o przedstawicielu np. myśli hinduskiej z XIX lub XX wieku, to nie jest on uważany za „autentycznego” przedstawiciela owej myśli, ponieważ w toku swojej filozoficznej edukacji podlegał wpływom zachodnim. Jednak nikt nie zakwestionuje faktu, że Heidegger nie jest filozofem europejskim tylko dlatego, że czytał pisma Lao-Tsy. W tej sytuacji filozofowie nie-zachodni są rozdarci: albo będą zachowywać się jak filozofowie zachodni i wówczas nie będą uznawani za „autentycznych reprezentantów” swoich kultur, albo też będą zachowywać się tak, jak zachowaliby się ich przodkowie, i wtedy również nie zostaną potraktowani jak „prawdziwi filozofowie”, przynajmniej nie w takim sensie, że współcześni akademiccy filozofowie czuliby się zobowiązani do poważnego potraktowania ich argumentów.

Kolejny argument, jaki wytacza Wimmer, to uwaga, iż w toku edukacji z zakresu filozofii, jeśli pojawiają się wzmianki o tym, że konfucjanizm wpłynął na oświecenie, a islamska metafizyka na filozofię średniowiecza, to tylko w takim świetle, aby pokazać jak owe obce prądy wpłynęły na rozwój tej wyjątkowej tradycji myśli - myśli zachodniej, a nie jako równorzędny partner w dialogu.

Pytanie zatem, jakie się pojawia, to: jak w takich okolicznościach mają zachować się historycy filozofii? Przede wszystkim filozofia powinna zrekonstruować swoją własną ideologię, aby ustanowić egalitarną podstawę do komunikacji pomiędzy różnymi systemami filozoficznymi z różnych części naszego globu, podstawę do komunikacji polilogicznej. Sukces w tej materii przewiduje Wimmer tylko w sytuacji, jeśli zostanie przyjęte założenie, że wszystkie tradycje i sposoby myślenia są względem siebie epistemologicznie równoważne.

Wimmer pokazuje również prosty, praktyczny sposób, od którego można zacząć, chcąc uprawiać filozofię w ujęciu międzykulturowym: to publikowanie książek dotyczących filozofii czy to chińskiej, czy hinduskiej, nie w serii „indologia” lub w publikacjach przeznaczonych dla etnografów czy „poszukiwaczy ducha Azji”, ale w seriach dotyczących właśnie historii filozofii. 
Druga kwestia poruszona przez Wimmera, to związek filozofii z językiem, w jakim jest ona wyrażona. Filozofowie nigdy nie będą mieli niczego innego niż ich słowa, aby pokazać to, o czym myślą. Słowa z określonych języków, słowa, które powstały w kręgu określonej tradycji kulturowej. A z drugiej strony, jeśli chcą oni filozofować, to chcą, by efekty tego filozofowania były ponadkulturowe, obowiązujące dla wszystkich. Czy w związku z tym możemy w ogóle mówić, że filozofia międzykulturowa jest w ogóle możliwa? Jak mamy osiągnąć transkulturowe, globalnie obowiązujące „wglądy” czy „prawdy”, skoro nasze postrzeganie świata - i równocześnie środki jego wyrażania - są z konieczności ograniczone ${ }^{1}$. Pierwszą możliwością wyjścia z tego dylematu jest zawierzenie jednemu językowi jako wyrazicielowi myśli ludzkiej - tę drogę wybrali Hegel i Heidegger. Drugi sposób to skonstruowanie metody obowiązującej wszystkich - to z kolei propozycja Kartezjusza czy Husserla. Jasne jest jednak, że współcześnie żadne z tych rozwiązań nie znalazłoby uznania wśród wszystkich filozofów i historyków filozofii. Jako kolejną próbę rozwiązania tego dylematu Wimmer podaje ideę „dekolonizacji pojęciowej” zaproponowanej przez afrykańskiego filozofa, Kwasi Wiredu. W myśl tej koncepcji należałoby dokonać porównania pojęć (np. prawda, rzeczywistość, wiedza, osoba, przestrzeń, czas, życie, materia itp.) występujących w różnych językach, a po dokonaniu porównania przełożyć je wszystkie na nową terminologię. Jednak i ten pomysł jest skazany na niepowodzenie, ponieważ każde z owych pojęć powstaje w określonej tradycji, a nie jesteśmy w stanie stworzyć zupełnie nowej tradycji dla nowych sformułowań terminologicznych, czy też tworzyć takie sformułowania w oderwaniu od tradycji. Czy zatem wyjściem miałoby być kultywowanie poszczególnych etnicznych tradycji i nazywanie ich „filozofiami”? Wtedy maleje problem translacji i interpretacji, ale równocześnie maleje grupa odbiorców, do których owa „filozofia” jest skierowana.

Zadanie, jakie w tym punkcie staje zatem przed filozofią, jest trojakie: refleksja nad kulturowością i regionalnością każdego sposobu myślenia na każdym poziomie, poszukiwanie uniwersalnie ważnych argumentów i koncepcji oraz sprawiedliwe odnoszenie się do poszczególnych regionalnych tradycji filozoficznych.

Trzecim zagadnieniem, którym zajmuje się Wimmer, jest kwestia tzw. etnofilozofii, czyli takiego podejścia do filozofii, które wydaje się rozwiązywać dylemat pomiędzy uniwersalizmem i partykularyzmem poprzez negowanie uniwersalizmu i propagowanie podejścia „pozwólmy rozkwitnąć tysiącu kwiatom”. Jednak, zdaniem Wimmera, propozycja etnofilozofii nie rozwią-

\footnotetext{
1 Wimmer idzie nawet krok dalej i nazywa ten rodzaj postrzegania „zaściankowym”.
} 
zuje powyższego dylematu. $\mathrm{Z}$ jednej strony zrozumiałe są protesty intelektualistów $\mathrm{z}$ byłych kolonii wobec narzucania określonego paradygmatu myślenia przez byłych kolonizatorów, jest to naturalna reakcja przeciwko akademickim i kulturowym centrom, które ustalają standardy wiedzy i myślenia i narzucają je peryferiom. Jednak uznanie, że każda tradycja kulturowa ma prawo do wyrażenia swoich myśli i nazywanie tego wyrażania czyjąś własną filozofią prowadziłoby do sytuacji, w której „rozkwitają setki kwiatów”, różnych od siebie, prawdopodobnie pod każdym względem, co wygląda jak sytuacja wzorcowa $\mathrm{w}$ erze postmodernizmu, ale uniemożliwia porozumienie.

Co jest potrzebne w takiej sytuacji? Wimmer odwołuje się do możliwości argumentowania filozoficznego samego w sobie. Pojawia się tu pytanie: jakie są kryteria, metody bądź dowody i gdzie można je znaleźć, które uprawniłyby nas do stwierdzenia, że coś jest prawdziwe lub fałszywe. Wydaje się, że zdaniem większości etnofilozofów można za pomocą danego przysłowia rodem z plemienia Gikuyu obalić (filozoficzną lub jakąkolwiek inną) argumentację. Z tym naturalnie Wimmer się nie zgadza, bo czy jakiekolwiek przysłowie bądź mądrość ludowa jest w stanie podważyć teorię imperatywu kategorycznego Kanta i czy to ma być sposób, w jaki miałaby toczyć się dyskusja między różnymi tradycjami? Jakkolwiek przysłowia uczą nas czasem ostrożności, tak nie uczą nas sposobu, w jaki zdobywać wiedzę. Dylemat, jaki powstaje w związku z etnofilozofiami, jest następujący: z jednej strony - powtórzmy raz jeszcze - jest to jak najbardziej uzasadnione, aby zwracać uwagę na tradycje, które dotychczas były zaniedbywane i ignorowane. Z drugiej jednak strony, takie emancypacyjne projekty regularnie sięgają do zachodnich koncepcji i metod analizy. Zatem wrażenie, jakiemu jesteśmy poddani, jest dwojakie: jest „ten” Zachód, który niejednokrotnie był niesprawiedliwy wobec innych tradycji, ale to właśnie zachodnie konceptualizacje są nie tylko właściwe, ale wręcz konieczne dla interpretacji jakiejkolwiek tradycji myśli.

Komu i na jakiej podstawie należy przyznać rację? Chcąc odpowiedzieć na to pytanie ponownie musimy odwołać się do naszych własnych umysłów. Dalej będziemy jednak używać różnych języków, aby wyrazić nasze myśli. Każdy z tych języków ma swoje cechy szczególne, nieprzekładalne dosłownie na inne języki, żaden nie będzie najbardziej odpowiedni do wyrażenia tego, o czym myślimy. Nadal będzie toczyła się gra różnicowania i definiowania. I nigdy nie będziemy mieli pewności, że którekolwiek z naszych pojęć lepiej oddaje naturę rzeczywistości niż inne. Nie zapominajmy, że filozofowie nie dysponują innymi narzędziami niż słowa, aby pokazać to, o czym myślą, i wszystkie te słowa są i będą zakorzenione w pewnym określonym, szczególnym kulturowym otoczeniu i doświadczeniu. Filozofia międzykulturowa oznacza świa- 
domość wielości i różnorodności kultur w dziejach ludzkości przy równoczesnym uniknięciu popadania $\mathrm{w}$ relatywizm. Takie podejście $\mathrm{w}$ przyszłości możemy odnaleźć na drodze współpracy, a nie separacji.

Ostatnim zagadnieniem poruszanym przez Wimmera są konsekwencje dla historiografii przyjęcia międzykulturowego podejścia do filozofii. Pierwszą z konsekwencji jest (samo-)krytyczna ocena filozofii jako profesji. Należy uznać, że jakiekolwiek profesjonalne kształcenie filozofów, które zrównuje ogólne pojęcie „filozofia” z kulturowo uwarunkowanym pojęciem „filozofia zachodnia” lub „filozofia europejska” jest mylące (takie bowiem założenie panowało przez lata w poglądach większości filozofów Zachodu, a najdobitniejszy swój wyraz znalazło w myśli Heideggera, który uważał wyrażenie „filozofia europejska” za pleonazm [Kimmerle, 2002: 46]). Konieczną podstawą do proponowanej zmiany jest wyjściowe założenie o krytyce wszelkiego centrycznego myślenia i przekształcenie go w teorię filozofii nie-centrycznej (noncentristic philosophy). Drugim krokiem - według Wimmera - jest stworzenie przestrzeni dla polilogu różnych tradycji. Choć pytanie, jakie tu się nasuwa, budzi jednak pewne wątpliwości, bo czy możliwa filozofia w warunkach polilogu będzie w ogóle możliwa? Trzecia propozycja odnosi się do opisywania i wyjaśniania historii filozofii - Wimmer pisze, że należy unikać obrazu historii jako jednego kontinuum. Raczej należy ustalić koncepcję wielu kontinuum (concert continua), które istnieją względnie niezależnie od siebie.

Do nowej historii filozofii prowadzą dwie drogi: pierwsza polega na analizie niekonsekwencji w zachodnim przedstawianiu kontinuum - tu jako przykład Wimmer podaje filozofię Kanta, która przez różnych historyków filozofii jest przedstawiana czasem w całkowicie odmienny sposób. Dla Bertranda Russela Kant to przede wszystkim ważny i wpływowy epistemolog, którego głównym osiągnięciem była „Krytyka czystego rozumu”, natomiast dla historyków z Rosyjskiej Akademii Nauk Kant był ważnym metodologiem nauki zanim zaplątał się w sprzeczności związane z rzeczywistością i doświadczeniem. Wimmer konkluduje, że każdy historyk filozofii pisze niejako swoją własną opowieść, nie ma więc jednej historii filozofii Kanta, a tym samym nie ma też jednej historii filozofii zachodniej. Względność punktów widzenia jest pierwszą lekcją, jaką pobieramy czytając historię filozofii.

Druga $z$ dróg prowadzących do nowego podejścia do historii filozofii to zastosowanie różnych kategorii i koncepcji z tradycji nie-zachodnich i uzyskanie w ten sposób nowej historii filozofii. W tradycji zachodniej powszechnie stosuje się dychotomie typu "materializm - idealizm”, „racjonalizm - empiryzm”, „teoria - praktyka”. Motywem do tworzenia takich dychotomii jest fakt, że w zachodnich dyskusjach jest głęboko zakorzeniona zgoda co do tego, 
że istnieją dwa możliwe źródła wiedzy: zmysły lub rozum (albo jakaś ich kombinacja). Natomiast filozofowie hinduscy wyróżniają sześć źródeł możliwej wiedzy. Historyk filozofii nie jest w stanie zdecydować, która z tradycji ma rację. Jego obowiązkiem jest jednak opisać i wyjaśnić filozoficznie ważne tradycje i myśli jak najbardziej sprawiedliwie i w sposób jak najbardziej zróżnicowany. Dychotomiczne podziały mogą okazać się niewystarczające, zatem dla uzyskania pełnego obrazu historii filozofii konieczna jest współpraca naukowców pochodzących z różnych tradycji kulturowych. Tylko w ten sposób można uzyskać innowacyjne formy i treści dotyczące periodyzacji, klasyfikacji i interpretacji.

Ostatnia propozycja Wimmera to rozwinięcie praktyk odpowiadania na pytania, które stawia filozofia, z uwzględnieniem możliwie wielu tradycji myśli, czyli komunikacji polilogicznej. Jako przykład podaje dyskusję dotyczącą "człowieczeństwa” (humanity) z centralnym punktem w postaci praw człowieka. Dyskusja prowadzona w kontekście międzykulturowym powinna odnosić się nie tylko do pojęć takich jak „humanum” lub „Menschheit”, ale również do pojęcia „muntu” w języku Bantu lub „ren” w jezyku chińskim i innych równie ważnych koncepcji.

Podsumowując rozważania na temat filozofii międzykulturowej warto jeszcze zwrócić uwagę na to, że od zawsze marzeniem filozofów było, aby ich poglądy miały wymiar ponadkulturowy, obowiązujący niezależnie od kulturowych i religijnych uwarunkowań. W obecnych czasach międzykulturowe podejście do filozofii staje się koniecznością, która wyrasta z bieżącej sytuacji, to już nie jest wybór, ale oczywistość.

Program międzykulturowej filozofii można streścić zasadniczo w dwóch głównych punktach: po pierwsze, należy spojrzeć na historię filozofii w świeży sposób, a po drugie, potrzeba polilogu w rozważaniu każdego pytania filozofii. Również Heinz Kimmerle stwierdza jasno, że filozofia stanie się międzykulturowa - bo jeśli nie, to nie będzie niczym innym jak akademickim zajęciem bez społecznego znaczenia [Kimmerle, 2002: 11].

Wimmer ostatecznie formułuje regułę, która ma być pomocna w międzykulturowym podejściu do filozofii: nie oczekuj, że koncepcje filozoficzne są dobrze ugruntowane, jeśli ich autorzy sięgają do źródeł jednej tylko tradycji kulturowej. Tę regułę można również sformułować w sposób pozytywny: jeśli to tylko możliwe, poszukuj transkulturowego zazębiania się filozoficznych koncepcji i teorii, ponieważ jest prawdopodobne, że dobrze ugruntowane teorie pojawiły się w więcej niż jednej tradycji kulturowej [Wimmer, 2007: 8].

$\mathrm{Na}$ koniec chciałabym jeszcze krótko odwołać się do obrad Komisji Gulbenkiana na rzecz Restrukturyzacji Nauk Społecznych, które odbyły się w la- 
tach 1994-1995. Pytaniem, jakie postawiła sobie Komisja było, czy centralnym dylematem nauk społecznych na ówczesnym etapie rozwoju nie powinno być przezwyciężenie utrwalonej struktury dyscyplin. Pod hasłem „Otwórzmy nauki społeczne” toczyła się refleksja nad stanem nauk społecznych oraz nad ich przyszłością. Warto przywołać tu myśl afrykańskiego uczonego Engelberta Mvenga, który już w 1978 roku pisał: „Zachód dziś się z nami zgadza, że droga do prawdy przebiega licznymi ścieżkami, innymi niż arystotelesowska, innymi niż tomistyczna logika czy heglowska dialektyka. Lecz same nauki społeczne i humanistyczne muszą dopiero zostać poddane dekolonizacji" [Flis, 1999: 63]. To nawoływanie do dekolonizacji było wezwaniem do przekształcenia układów władzy, które stworzyły tę szczególną formę do instytucjonalizacji nauk społecznych, jaką dzisiaj znamy. Jedną z konsekwencji prowadzonej debaty nad przyszłością nauk społecznych było żądanie takiej nauki społecznej, która byłaby bardziej „wielokulturowa” lub „międzykulturowa”. Chodziło tu z jednej strony o dopuszczenie do głosu grup dotychczas pomijanych oraz o inkorporowanie doświadczeń tych grup dla uzyskania obiektywnej wiedzy o zachodzących procesach społecznych. To wezwanie dotyczy również większej wielojęzyczności w świecie akademickim, ponieważ - jak argumentują uczestnicy debaty - „świat, w którym wszyscy badacze społeczni posiadaliby roboczą znajomość kilku głównych języków akademickich, byłby światem, w którym uprawiano by lepszą naukę społeczną" [ibidem: 92]. Przyjęcie polityki szerokiego otwarcia się na badanie i edukację z zakresu różnych kultur to postulat Komisji Gulbenkiana, który również wyznacza drogę filozofii międzykulturowej.

\section{Bibliografia}

Esterman J. (1978), Filosofía andina. Estudio intercultural de la sabiduría autóctona andina, Quito.

Flis A. (red.) (1999), Wyzwania wobec nauk społecznych u progu XXI wieku, Kraków.

Fornet-Betancourt R. (2002), An Alternative to Globalization: Theses for The Development of an Intercultural Philosophy, (in:) L.M. Alcoff, M. Sáenz (eds.), Latin American Perspectives on Globalization: Ethics, Politics and Alternative Visions, Rowman \& Littlefield Publishers, Inc.

Kimmerle H. (2002), Interkulturelle Philosophie zur Einführung, Hamburg.

Škof L., Thinking between cultures. Pragmatism, Rorty and Intercultural Philosophy, http:// www.ideasyvalores.unal.edu.co/archivos/PDF138/06_skof.pdf (z dnia 23.06.2010).

Szulakiewicz M. (2006), Dialog i metafizyka, Toruń.

Wimmer F.M. (2007), Cultural Centrism and Intercultural Polylogues in Philosophy, "International Review of Information Ethics", 09, Vol. 7, http://www.i-r-i-e.net/inhalt/007/09wimmer.pdf (z dnia 23.06.2010). 
Wimmer F. (1996), Is Intercultural Philosophy a New Branch or a New Orientation in Philosophy?, http://homepage.univie.ac.at/franz.martin.wimmer/intpheng95.pdf ( $\mathrm{z}$ dnia 13.06.2010).

Wojcieszak J. (2006), O statusie latynoamerykańskiej filozofii kultury, (w:) Z. Rosińska, J. Michalik (red.), Co to jest filozofia kultury?, Warszawa. 


\section{Intercultural philosophy - a new approach to philosophy}

The article presents shortly a new approach to philosophy, namely intercultural philosophy. The author describes two views of intercultural philosophy, one presented by Raul Fornet-Betancourt, a Latin-American philosopher, and the second presented by Franz Wimmer from Vienna University. Intercultural philosophy can be briefly described in two points: first, there is a need to look at the history of philosophy in a new way, and second, each systematic philosophical question should be considered in the polylogue communication (i.e. concerning possibly many points of view from different cultural background). This new approach towards philosophy is also situated in a broader context of a general debate among social sciences that also requires an intercultural or multicultural approach in each research. 